\title{
Dengue virus infections in travellers returning from Benin to France, July-August 2010
}

P Gautret (surveillance@eurotravnet.eu)1,2, E Botelho-Nevers ${ }^{1}$, R N Charrel $^{3}$, P Parola $^{1,2}$

1. Infectious and Tropical Diseases Unit, Hôpital Nord AP-HM, Marseille, France

2. EurotravNet, the Network for travel medicine and tropical diseases of the European Centre for Disease Prevention and Control, Marseille, France

3. Virology laboratory, AP-HM hospital Timone, Marseille, France

Citation style for this article:

Gautret P, Botelho-Nevers E, Charrel RN, Parola P. Dengue virus infections in travellers returning from Benin to France, July-August 2010. Euro Surveill.

2010;15(36):pii=19657. Available online: http://www.eurosurveillance.org/ViewArticle.aspx?Articleld=19657

Article published on 9 September 2010

In July and August 2010, two cases of dengue fever were diagnosed in travellers returning from Benin to France. These two cases exemplify that dengue fever should be considered in febrile travellers, even those returning from areas where the infection is not usual.

Dengue virus infections are increasingly reported in travellers returning from West Africa [1,2]. Dengue cases detected in sentinel travellers may inform the international community of the onset of epidemic activity in specific areas. We report two cases of dengue fever identified by a EurotravNet site in Marseille, France, in two travellers returning from Benin. Up to 7 September 2010, no other dengue fever cases were reported in the EuroTravNet network from this area.

The first case was a French expatriate in his 40s, who had been resident in Cotonou, Benin for more than a year. When returning to France in July 2010, he suffered from fever, headaches and myalgias on the plane and took an anti-malaria drug, coartem, as a self-treatment, with no significant effect. Five days later he presented to the emergency ward in a hospital near Marseille and was transferred to the Tropical and Infectious Disease ward in Hôpital Nord, Marseille. On admission, the body temperature was $38{ }^{\circ} \mathrm{C}$, the patient reported having dysphagia and the clinical examination revealed a diffuse non-petechial rash. Blood cultures were negative for bacteria and malaria was ruled out by microscopic blood examination. Serology was positive for IgM and IgG against dengue virus (ELISA, Euroimmun). In order to exclude possible cross-reaction with other flaviviruses, the presence of antibodies specific for West Nile virus and tick-borne encephalitis virus was tested by an ELISA test (Euroimmun), and that for yellow fever virus (YFV) was tested by in-house immunofluorescence using a previously reported method [3]. Only IgG against YFV were detected. The patient had previously been vaccinated against yellow fever. PCRs for dengue and chickungunya virus infections were negative, using published protocols $[4,5]$.
The second case was a migrant from Benin in her 30s, established in France for over five years, who visited friends and relatives in Cotonou in July and August 2010. During her stay, she suffered from fever $\left(39^{\circ} \mathrm{C}\right)$, headaches, arthralgias, myalgias, nausea, anorexia and fatigue. On day 4 , she consulted in a clinic in Benin, where she was given quinine despite negative blood examination for malaria. She remained febrile until day 7. On returning to the south of France (on day 17), she was seen by her general practitioner for asthenia. Dengue serology was positive for IgM and IgG (ELISA, Biotrin). Serology for human immunodeficiency virus (HIV) infection (MEIA Abbot Axsym, HIV Ag/Ab Combo), acute hepatitis A, B and C (CMIA Abbot Axsym), amoebiasis (ELISA, Ridascreen, IFI bioMérieux), schistosomiasis (ELISA, Bordier) and falciparum malaria (indirect immunofluorescence, bioMérieux) were negative. No PCR was attempted because the patient had no chance to be been viraemic 17 days following the onset of fever, nor any other flavivirus serology.

The detailed laboratory findings for both cases are shown in the Table. Both had non-complicated dengue

\section{TABLE}

Laboratory findings for two cases of dengue fever in travellers returning from Benin, France, July-August 2010

\begin{tabular}{|l|c|c|}
\hline $\begin{array}{l}\text { Time between onset and blood } \\
\text { sampling }\end{array}$ & 5 days & 18 days \\
\hline Leukocyte count/ $\mu \mathrm{L}$ & 3,200 & 5,100 \\
\hline Platelet count $/ \mu \mathrm{L}$ & 99,000 & 520,000 \\
\hline SGOT $(U / L)$ & $240(5 N)$ & $41(1.2 \mathrm{~N})$ \\
\hline SGPT $(U / L)$ & $264(4 N)$ & $85(1.5 N)$ \\
\hline GGT $(U / L)$ & $176(3 N)$ & $28(1 N)$ \\
\hline Serology & $\operatorname{IgM}+\operatorname{IgG}{ }^{a}$ & $\operatorname{IgM}+\operatorname{IgG}{ }^{\text {b }}$ \\
\hline
\end{tabular}

N: normal upper value; GGT: gamma-glutamyl transferase; SGOT: serum glutamic oxaloacetic transaminase; SGPT: serum glutamic pyruvic transaminase.

${ }^{a}$ Dengue virus ELISA IgG and IgM (Eurolmmun, Biodavance France. ${ }^{b}$ Dengue virus ELISA IgG and Ig M (Biotrin France). 
fever, according to the new classification of the World Health Organization [6].

Dengue fever is not a common diagnosis in travellers returning from Benin (in addition to the presented cases we are aware of three published cases since $2006[7,8])$. Nevertheless, it was decided to test for dengue virus in the first patient because of the typical clinical presentation and because dengue virus had been detected in our unit shortly before, in travellers returning from West Africa [1] and from islands in the Indian Ocean [9]. For the second patient, the general practitioner decided to test for dengue virus infection for retrospective diagnosis because, working part-time in the tropical and infectious disease ward, he was aware of the diagnosis in the first patient.

The first serological evidence of transmission of dengue virus in Benin was provided by a seroprevalence study conducted in asymptomatic Germans working overseas for the German Aid Agency 'Deutscher Entwicklungsdienst' from 1987 to 1993 [10]. Two cases of dengue virus infection were also reported in 2006 in travellers returning from Benin to France $[2,7]$. Because a confirmed case of dengue 3 virus infection (positive PCR for detection and typing using published protocols $[4,5])$ in a traveller returning from Togo to Marseille was evidenced this summer (data not shown), and because a confirmed case of dengue 3 virus infection was reported in a Japanese travellers returning from Benin in July [8], we suspect our two cases to be type 3 dengue virus infections too. Dengue virus serotype 3 was also recently identified in European travellers returning from Côte d'Ivoire [1,11], from Eritrea and Senegal [2], and from the Comoros islands and Zanzibar [9], and in an outbreak in Cape Verde [2], which suggests that this serotype has emerged in different parts of Africa.

So far there have been no reports about a current outbreak of dengue virus in Benin. However, local investigations are of interest to identify a possible outbreak in Benin, and surveillance should be reinforced among febrile travellers returning from Benin and neighbouring countries to detect additional cases. In conclusion, these two cases exemplify that dengue fever should be considered in febrile returned travellers, even in areas where the infection is not usual.
4. Leparc-Goffart I, Baragatti M, Temmam S, Tuiskunen A, Moureau G, Charrel R, et al. Development and validation of real-time one-step reverse transcription-PCR for the detection and typing of dengue viruses. J Clin Virol. 2009;45(1):61-6.

5. Moureau G, Temmam S, Gonzalez JP, Charrel RN, Grard G, de Lamballerie X. A real-time RT-PCR method for the universal detection and identification of flaviviruses. Vector Borne Zoonotic Dis. 2007;7(4):467-77.

6. World Health Organization. Dengue: guidelines for diagnosis, treatment, prevention and control. New edition. Geneva: World Health Organization; 2009. ISBN 97892 4154787 1. Available from: http://whqlibdoc.who.int/ publications/2009/9789241547871 eng.pdf

7. Institut de Veille Sanitaire. Bulletin Hebdomadaire International. 2008; №151. Available from: http://www.invs. sante.fr/international/bhi/bhi_120808.pdf. French.

8. ProMED-mail. Dengue/DHF update 2010 (44). Archive number 20100826.3010. Boston US: International Society for infectious diseases; 26 August 2010. Available from: http://www. promedmail.org

9. Gautret P, Simon F, Hervius Askling H, Bouchaud O, LeparcGoffart I, Ninove L, et al. Dengue type 3 virus infections in European travellers returning from the Comoros and Zanzibar, February-April 2010. Euro Surveill. 2010;15(15):pii=19541. Available from: http://www.eurosurveillance.org/ViewArticle. aspx?Articleld $=19541$

10. Eisenhut M, Schwarz TF, Hegenscheid B. Seroprevalence of dengue, chikungunya and Sindbis virus infections in German aid workers. Infection. 1999;27(2):82-5.

11. Dengue in Africa: emergence of DENV-3, Côte d'Ivoire, 2008. Wkly Epidemiol Rec. 2009 Mar 13;84(11-12):85-8. Available from: http://www.who.int/wer/2009/wer8411_12.pdf

1. Ninove L, Parola P, Baronti C, De Lamballerie X, Gautret $P$, Doudier $B$, et al. Dengue virus type 3 infection in traveler returning from West Africa. Emerg Infect Dis. 2009;15(11):1871-2.

2. Franco L, Di Caro A, Carletti F, Vapalahti O, Renaudat C, Zeller $\mathrm{H}$, et al. Recent expansion of dengue virus serotype 3 in West Africa. Euro Surveill. 2010;15(7):pii=19490. Available from: http://www.eurosurveillance.org/ViewArticle. aspx?Articleld $=19490$

3. Fulhorst CF, Monroe MC, Salas RA, Duno G, Utrera A, Ksiazek TG, et al. Isolation, characterization and geographic distribution of Caño Delgadito virus, a newly discovered South American hantavirus (family Bunyaviridae). Virus Res. 1997;51(2):159-71 